\title{
PARASITES OF OREOLEUCISCUS POTANINI (CYPRINIDAE) FROM LAKES OF KHAR US NUUR NATIONAL PARK (MONGOLIA)
}

\author{
Darya I. Lebedeva ${ }^{1, *}$, Bud Mendsaikhan², Galina A. Yakovleva ${ }^{1}$, Dmitry O. Zaytsev ${ }^{3}$ \\ ${ }^{1}$ Institute of Biology of the Karelian Research Center of RAS, Russia \\ *e-mail:daryal78@gmail.com \\ ${ }^{2}$ Institute of Geography and Geoecology, Mongolian Academy of Sciences, Mongolia \\ ${ }^{3}$ Petrozavodsk State University, Russia
}

Received: 25.03.2020. Revised: 03.05.2020. Accepted: 27.07.2020.

\begin{abstract}
Freshwater ecosystems of Mongolia belong to the three major Central Asian drainage systems: Arctic drainage, Amur River drainage, and Central Asian Internal drainage. The Great Lakes Depression takes considerable part of the latter. One of the few fish species living there, Oreoleuciscus potanini, is the most common and widespread endemic species in the Central Asian region. Parasitological surveys on $O$. potanini from the Great Lakes Depression have not occurred regularly in recent years. Consequently, this study was conducted to explore the species diversity of helminth parasites in O. potanini in the three lakes of Khar Us Nuur National Park. In total, 52 O. potanini specimens were collected from the lakes Khar, Khar Us and Durgen and sampled in August 2012. In addition to the parasites, the age and diet spectrum of the fish species were studied. The fish were examined for infection with ecto- and endo- macroparasites. The species composition of Diplostomum spp. metacercariae from the eyes of fish was investigated using a molecular approach. In the lakes Khar and Khar Us the fish age ranged from four to 32 years old and from eight to 35 years old, respectively. Fish of four age groups $(9,10,11$ and 14 years old) were in Lake Durgen. Algae and various insects, including Chironomida larvae were the main food of the $O$. potanini in all three lakes. When the diet was investigated we found that in Lake Durgen Cladocera crustaceans were the significant component in the fish diet, and no fish was found in the O. potanini diet there. During the study 26 parasites species were identified from the three lakes. The total fauna is represented by four phyla, including Acanthocephala (one species), Annelida (one species), Nematoda (four species), Platyhelminthes (20 species). The last group was the most numerous and diverse, including three species of Cestoda, six species of Monogenea and 11 species of Trematoda. Five species of parasites were specific to O. potanini only (monogeneans Gyrodactylus mongolicus, G. oreoleucisci, G. pewsowi, nematodes Philometra oreoleucisci and Rhabdochona humili). The other helminthes exhibited a low host-specificity, infecting a wide range of fishes in the Holarctic. The larvae of endohelminthes predominate in the parasite fauna. The majority of these parasites enter the fish via various invertebrate species during $O$. potanini's feeding. Our study provided novel data on the species diversity of Diplostomum spp. metacercaria in $O$. potanini's eyes. They were represented by three species: Diplostomum spathaceum, D. pseudospathaceum and Diplostomum sp. LIN2. The species richness and diversity of parasites were much higher for $O$. potanini from the lakes Khar and Khar Us (26 species), than that for O. potanini of Lake Durgen (15 species). The possible reason for the absence of some parasites in Lake Durgan is an increased water salinity. It is likely that, despite the potential for the fish to exist under conditions of an elevated salinity, parasites (or their invertebrate hosts) are not adapted to it. Our findings clarified the known parasite diversity in lakes of the Khar Us Nuur National Park, indicating that the Great Lakes Depression ecosystem may be characterised by many unique parasite assemblages. The results of investigation on the parasitic fauna of $O$. potanini confirm a review of the evolutionary youth of this fish group.
\end{abstract}

Key words: Dzabkhan River basin, endemic, fish, Great Lakes Depression, helminthes, species composition

\section{Introduction}

Monitoring studies in the Protected Area systems cover numerous biota parameters. On their basis criteria for assessing the natural environment and future trends in ecosystem change are identified. One of the biological pollution forms is «parasitic pollution», which can be defined as penetration of parasitic organisms into environment and subsequent reproduction. Parasites comprise a substantial proportion of global biodiversity and exert important ecological influences on hosts, communities and ecosystems, but our knowledge of how parasite populations respond to human impacts is in its infancy (Wood et al., 2013). In this regard, it is relevant to develop methods of parasitological research as an important diagnostic tool for biomonitoring in Protected Areas.

One of the global issues is to save biodiversity of water ecosystems with a high rate of endemism. Moreover, fish, serving as a fundamental component of any water ecosystem, represent an important resource for the economy. The specially introduced parasites are a potentially threat to fish health and population abundance. Specialisation of the parasite has been viewed as the consequence of a long-term evolutionary process, especially true in the case of isolated populations (Sasal et al., 2004).

Therefore, in different countries, research has been conducted for a long time, not only for fish, but also for their parasites in Protected Areas. 
Some of the investigations concerned the parasite communities and species composition in different fish species (Mudry \& Anderson, 1977; Boomker, 1994; Murcia et al., 2006; Morozińska-Gogol, 2007, 2009; Butorina et al., 2008; Shukerova \& Kirin, 2008; Moravec \& Bakenhaster, 2010; Sandlund et al., 2010; Shukerova et al., 2010, 2017; Sokolov \& Gordeev, 2014; Chunchukova et al., 2016; Chunchukova \& Kirin, 2018; Rubtsova \& Kutsokon, 2018; Utevsky et al., 2018). Other studies devoted to different systematic groups include data on fish parasites in Protected Areas (Sasal et al., 2004; Galli et al., 2007; Kirjušina \& Vismanis, 2007; Székely et al., 2009; Wood et al., 2013; Halajian et al., 2018; Hoogendoorn et al., 2020). Some results make it possible to describe new parasite species or revise previous data on morphology, molecular characteristics and phylogeny, host specificity of fish parasites in Protected Areas (Moravec, 2001; Székely et al., 2012; Borkhanuddin et al., 2014; Stunžènas et al., 2014; Molnár et al., 2015; Presswell \& Blasco-Costa, 2019; Scholz et al., 2019). Despite numerous publications on fish parasites in different Protected Areas of the world, no such material exists in Mongolian Protected Areas in recent years.

Mongolia is situated on the Central Asian plateau comprising not only a large arid zone, but also a number of rivers and lakes. The freshwater ecosystems of Mongolia belong to the three major Central Asian drainage systems, including Arctic, Pacific Ocean or Amur River drainage, and Central Asian Internal drainage. Their watersheds are clearly separated (Sokolov \& Shatunovskiy, 1983).

In the Mongolian Central Asian Inland Basin, the fish fauna of the water bodies includes Thymallus brevirostris Kessler, 1879, and fishes of the genera Orthrias Jordan \& Fowler, 1903, Barbatula Linck, 1933, and Triplophysa Rendahl, 1933. However, Oreoleuciscus potanini Kessler, 1879 is the most numerous and widespread fish species in the region (Dgebuadze et al., 2003, 2014, 2017; Mendsaikhan et al., 2015; Prokofiev, 2016).

Oreoleuciscus potanini is an endemic species distributed extensively throughout the Central Asian fauna. The species is characterised by an extremely high morphological diversity. According to paleontological data, the formation of the genus Oreoleuciscus is associated with intensive tectonic transformations in Central Asia during the Pliocene - Pleistocene. The latter caused a deep restructuring of the relief and a number of water bodies in the region, which in turn led to an extreme decline of the fish fauna diversity (Sytchevskaya, 1989). The formation of Central Asian populations took place under extremely high varying abiotic conditions. Due to fluctuating environmental conditions and with almost complete absence of competition from other fish species, O. potanini in Central Asia had the opportunity to adapt to a range of habitats (Dgebuadze et al., 2020). Currently this group dominates in the fish population of most water bodies in the Central Asian Inland Basin of Mongolia, gradually expanding its range to the Baikal Lake Basin (Dgebuadze et al., 2003; Slynko \& Borovikova, 2012).

Oreoleuciscus potanini is a convenient fish species to study different environmental and evolutionary issues, including the parasite faunas. Since parasites co-evolve together with the hosts, information on their species composition can be useful to study as the taxonomy problems of the genus Oreoleuciscus, as any changes in their biology, habitat conditions, can also help to study the total dynamics of ecosystems. Information about the fish helminthes in water bodies of a unique Central Asian drainage basin, such as Khar Us Nuur National Park, would therefore offer the opportunity to use these systems as model for future studies of speciation.

The first data on fish parasites of varying geographical basins in Mongolia are fragmentary and were published a long time ago (Ergens \& Dulmaa, 1970; Moravec \& Ergens, 1970; Scholz \& Ergens, 1990). Later papers on fish parasites in water bodies of the Central Asian drainage basin were obtained and summarised (Kazakov \& Paranlejamts, 1985; Paranlejamts, 1993; Roitman et al., 1997; Pugachev, 2001, 2002, 2003, 2004; Batueva, 2011). However, recently there have been no new field-based studies carried out to examine the taxonomy and biology of both the fish hosts and parasites in this region. Due to the lack of any recent studies investigating fish parasites in the Central Asian drainage basin, a new study began in 2011 as a part of the Joint Russian-Mongolian Biological Expedition. During this period data on parasites of Rutilus rutilus Linnaeus, 1758, Perca fluviatilis Linnaeus, 1758, Barbatula conilobus Prokofiev, 2016 were obtained (Lebedeva et al., 2015, 2019). During the study, a new species Gyrodactylus was found, Gyrodactylus albolacustris Lumme, Ziętara \& Lebedeva, 2017, being described from Phoxinus phoxinus Linnaeus, 1758 using data on Mongolian parasites (Lumme et al., 2017). Additionally, special attention was paid to the study of several spe- 
cies of helminth parasites in $O$. potanini. The morphological variability of immature Proteocephalus torulosus (Batsch, 1786) from O. potanini was studied for the first time (Anikieva et al., 2013). Finally, species composition of trematodes from eyes of different fish species were studied using a molecular genetics approach (Lebedeva et al., 2020).

The current study was devoted to helminth parasites of $O$. potanini. It represents a part of a more comprehensive investigation of the parasitic fauna of fish carried out in the three lakes of the Khar Us Nuur National Park aiming to characterise parasites as an integral part of the biodiversity in the study region.

\section{Material and Methods}

The study was conducted in August 2012 in the Khar Us Nuur National Park (Great Lakes Depression, Western Mongolia) (Fig. 1). According to the WWF recommendation to preserve the unique natural Wetlands complexes of Mongolia, the Khar Us Nuur National Park was set up in 1997. This Protected Area is located in Western Mongolia, in the Great Lakes Depression. Forming parts of this region are the Chono Kharaih River, Mongolian part of the Altai ranges, and the eastern spurs of the Jagalant Hairhan. All of them are within the bounders of the Khar Us Nuur National Park. Lakes Khar Us, Khar and Durgen belonging to the Central Asian Drainless basin form the central part of this Protected Area.

Lake Khar Us (or Black Water Lake) is of tectonic origin and located at an altitude of 1157 $\mathrm{m}$ a.s.l. among the mountain ranges of Altai and Hangai. Its area is more than $180 \mathrm{~km}^{2}$, including more than 20 islands. This water body is connected by channels with the lakes Durgen and Khar (Dgebuadze et al., 2014).

Lake Khar (or Black Lake) is a freshwater lake located east of Lake Khar Us and connected to it by the channel Chono Kharaikh. Through the River Toul and the River Dzabkhan, it is connected with the lakes Airag and Khargas. Lake Khar's area is $57.48 \mathrm{~km}^{2}$. The lake is located at an altitude of $1132 \mathrm{~m}$ a.s.l. (Dgebuadze et al., 2014).

Lake Durgen is a closed brackish water lake covering approximately $30 \mathrm{~km}^{2}$, located south of Lake Khar and connected to it by the channel Khamyn-Kholoy. The lake has a salinity of $4 \%$. It is one of a group of lakes that were once one large lake, which disappeared about 5000 years ago as a result of a climate change, becoming more arid (Dgebuadze et al., 2014).

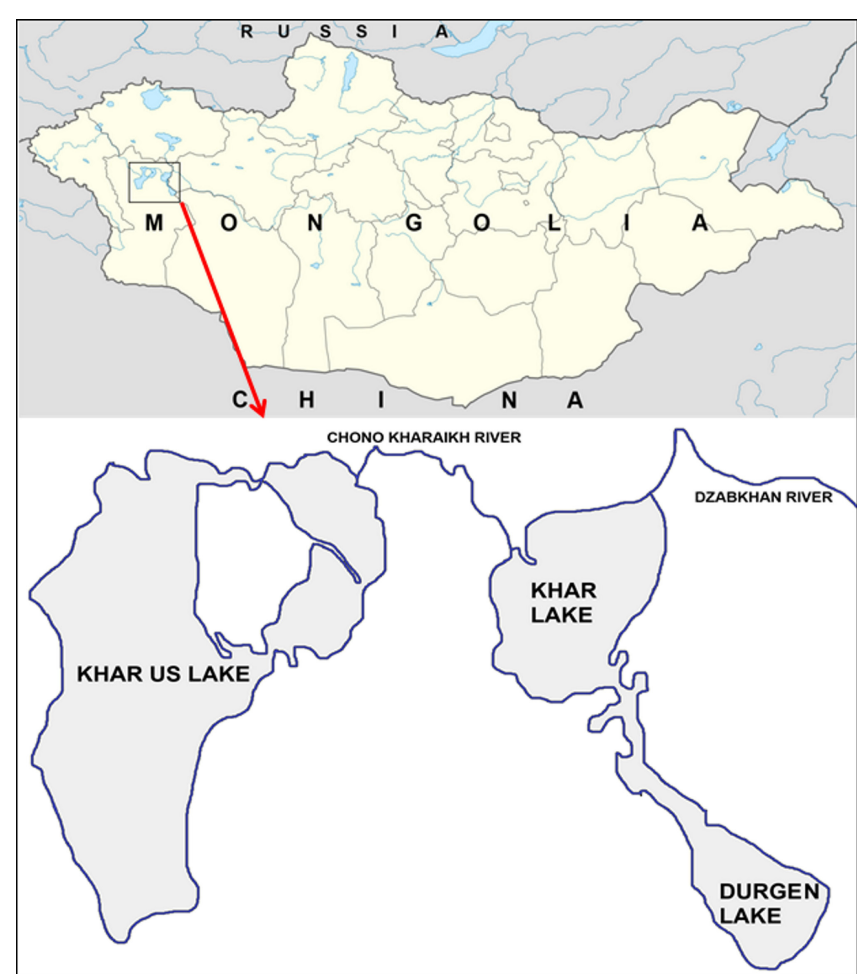

Fig. 1. The location of the Khar Us Nuur National Park and lakes Khar Us, Khar and Durgen in Mongolia.

In total, 52 specimens of Oreoleuciscus potanini from three lakes were investigated for their parasite fauna, including 22 ones from Lake Khar, 19 from Lake Us and 11 from Lake Durgen. The fish were caught with fixed gill nets with meshes of $40 \mathrm{~mm}$ and $50 \mathrm{~mm}$. The age of $O$. potanini was determined from the opercula (Chugunova, 1959; Pravdin, 1966). The fish diet was investigated using utilising methods according to Borutsky (1974) and Hyslop (1980). The value of particular food items in the diet was calculated by the frequency of occurrence.

The collection, fixation and laboratory processing of parasitological material were carried out according to Bykhovskaya-Pavlovskaya (1985). All fish organs were examined for infection with macroparasites. Mucus for the ectoparasites presence was scraped off the body surface and nasal cavities. Microscopic examination of organs and tissues for Protozoa and Myxosporidia invasion was not conducted. The parasites were identified using several keys (Scarlato, 1985, 1987; Khalil et al., 1994; Moravec, 1994; Sudarikov et al., 2002; Oroš et al., 2010; Pugachev et al., 2010). Methods of identification of Diplostomum spp. metacercariae were described by Lebedeva et al. (2020). Parasite data were interrogated and the prevalence (1) and the mean abundance (2) were calculated according to Bush et al. (1997) as follows: 


$$
\begin{gathered}
E=\frac{N_{i}}{N} \times 100 \%(1), \\
M=\frac{\sum n}{N}(2),
\end{gathered}
$$

where $\mathrm{E}$ is the prevalence, $\mathrm{M}$ is the mean abundance, $\mathrm{N}$ is the number of examined fish, $\mathrm{N}_{\mathrm{i}}$ is the number of infected fish, and $\sum_{n}$ is the total number of parasites found in all examined fish.

A systematic list of parasites is given according to the World Register of Marine Species (http://www.marinespecies.org/). Statistical analysis of the infection characteristics and distribution of the parasites was performed using Quantitative Parasitology software (Rózsa et al., 2000; Reiczigel et al., 2019).

\section{Results and Discussion}

In Lake Khar, the age of fish from control catches ranged from 4 to 32 years old. Although in this water body, the majority of examined fish was represented by specimens of 4-15 years old, in Lake Khar Us fish were of 8-35 years old. At the same time, the highest number of specimens were assigned to groups of 11 years old, 13 years old, and 16 years old. In Lake Durgen, we noted fish of 4 age groups: $9+, 10+, 11+$ and $14+$. The last two groups prevailed.

In all three investigated water bodies, $O$. potanini's diet was diverse (Fig. 2), a considerable part being represented by different groups of algae and various insects, including Chironomida larvae. In Lake Durgen, no fish was found in stomachs of the sampled $O$. potanini, although Cladocera crustaceans played a considerable component in their diet.

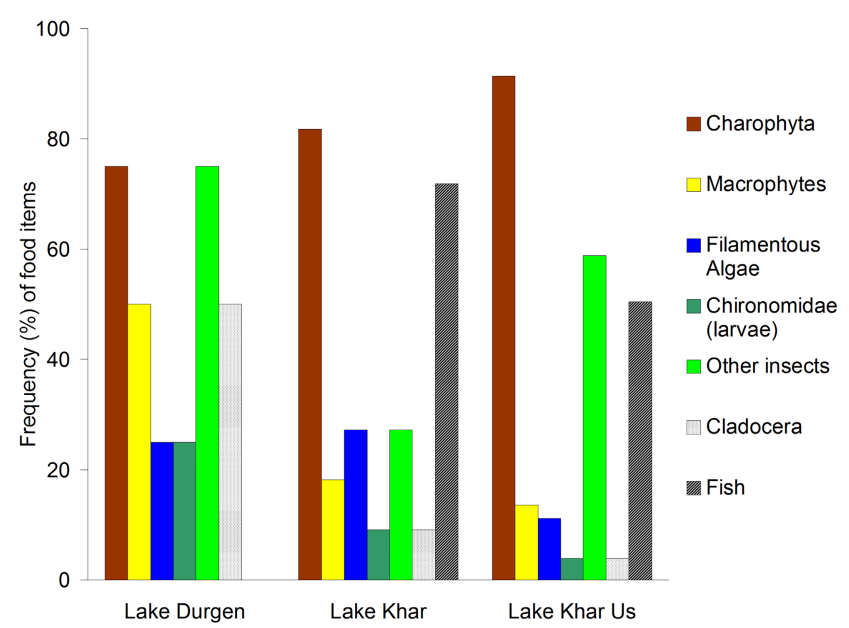

Fig. 2. Diet of Oreoleuciscus potanini in the lakes of Khar Us Nuur National Park in 2012.
The age of fish and the diet spectrum are among the main factors determining the parasitic fauna as well as the characteristics and distribution of fish infection. Also invasion levels and parasite species composition in $O$. potanini can vary significantly depending on the biology of the host as well as on the biology of the parasite itself.

Our investigation revealed that $O$. potanini hosted 26 parasite species in three lakes in total (Table 1). All fish examined were infected with parasites. The parasite list was represented by four taxonomic phyla: Acanthocephala (1 species), Annelida (1), Nematoda (4), Platyhelminthes (20). The latter group was the most numerous and diverse, including 3 species of Cestoda, 6 of Monogenea and 11 of Trematoda.

Seven parasite species (monogeneans Dactylogyrus ersinensis Spassky \& Roytman, 1960, D. oreoleucisci Ergens \& Dulmaa, 1970, Gyrodactylus llewellyni Ergens \& Dulmaa, 1967, G. mongolicus Ergens \& Dulmaa, 1970, G. oreoleucisci Ergens \& Dulmaa, 1970, G. pewsowi Ergens, 1980, and also the leech Piscicola geometra (Linnaeus, 1761)) were ectoparasites presented as adults found on skin, fins and gills. Additionally, specimens of $G$. oreoleuciscus were isolated from the nasal cavity of fish. With exception of $G$. llewellyni, all these parasite species were recorded in the three lakes studied. Among the monogeneans G. oreoleucisci, G. mongolicus and G. pewzowi had the highest prevalence and mean abundance. The other species were recorded singularly. The monogeneans are with a direct life cycle without intermediate hosts. Piscicola geometra infested quite a lot of fish samples, but the number of parasites was relatively low. According to Pugachev (2004), juvenile P. geometra hatching from their cocoons attach onto the surface of the fish in the second half of the summer. So, it is possible that in these lakes the wide distribution of the parasites in O. potanini populations is associated with two factors. First of them is collecting the fish during August. The second factor is that in the coastal zone, the feeding of the $O$. potanini with algae and macrophytes provides spatial contact with the leeches.

Another group predominated in the parasite fauna of $O$. potanin consisted of 18 endoparasite species (Table 1). All these parasites have a complex life cycle. Among them nematodes and cestodes are represented in fish by both larval and adult development stages, and Trematoda only by larvae. The majority of endoparasite species was 
found in the intestine (seven species). Among them, the cestoda Proteocephalus torulosus was the most numerous species, sampled in all three lakes. The Acanthocephala Neoechinorhynchus rutili (Müller, 1780) and nematode Rhabdochona humili Roytman \& Trofimenko, 1964 were also found in all three lakes. But their prevalence and mean abundance were low. Four intestine parasites, the nematode Pseudocapillaria tomentosa (Dujardin, 1843), cestoda Caryophyllaeides fennica (Schneider, 1902) and trematodes Allocreadium isoporum (Looss, 1894) and A. transversale (Rudolphi, 1802) infected fish in the lakes Khar and Khar Us only (Table 1). Allocreadium isoporum (Looss, 1894) was the most numerous species among them.

The majority of these parasites enter $O$. potanini, while the fish are feeding on invertebrates, in which the parasites are present. A considerable number of invertebrates inhabited the water bodies of the Great Lakes Depression (Krylov, 2013; Krylov et al., 2018; Prokin, 2018). The presence of Neoechinorhynchus rutile reflects the fish feeding by ostracods and amphipods as intermediate hosts for helminthes. A low prevalence and mean abundance indicated a low consumption by fish of ostracods and amphipods. The life cycle of Pseudocapillaria tomentosa as well as for Caryophyllaeides fennica is not exactly known. But most likely the fish is infected by them by feeding on oligochaetes (Khalil et al., 1994; Moravec, 1994). In the River Dzabkhan system, 12 species of oligochaetes have been identified (Dgebuadze et al., 2014; Prokin, 2018). The life cycle of Rhabdohona humili has not been studied, either. However, the parasites likely enter the fish body while feeding on Ephemeroptera (Pugachev, 2004).

Another species of cestode, Proteocephalus torulosus, was the most numerous and widespread among the cestodes on $O$. potanini in the three studied lakes. The development cycle of the Cestoda includes two obligate hosts, including Copepoda as the intermediate hosts and the fish as final hosts (Khalil et al., 1994). The age structure of the helminth populations and morphological characteristics of $P$. torulosus from Mongolian fish have been studied extensively (Anikieva et al., 1987, 2013; Anikieva, 2004). As a result, it was shown that the morphological variability of the reproductive group of $P$. torulosus is comparable with the high level and range of variability of the adult and mature parasite group from $O$. potanini. Assessment of the intrapopulation diversity of $P$. torulosus and its structure showed that the immature helminth group does not significantly differ from the mature one from $O$. potanini in Lake Nogon (Anikieva et al., 2013). In the water bodies of Mongolia, O. potanini is the only final host for P. torulosus. But the latter species is a widespread parasite of many $\mathrm{Cy}$ prinidae species in the Holarctic (Anikieva et al., 1987; Pugachev, 2002; Anikieva, 2004).

The findings of Allocreadium isoporum and A. transversale confirmed the predominance of benthos in the fish diet, since either amphipods or aquatic insect larvae serve as intermediate hosts of parasites. In Mongolia, A. transversale was revealed in Rutilus rutilus and Thymallus brevirostris, too. In total, five Allocreadium species were recorded in fish in Mongolia (Pugachev, 2003; Lebedeva et al., 2015). Allocreadium isoporum is a widespread parasite of Cyprinidae fish (Petkevičiūtè et al., 2010). The status and biology of $A$. transversale, as well as its distribution, need further research. So far, it is believed that the latter species is confined to the genera Misgurnus, Rhynchocypris and Phoxinus (Pugachev, 2004).

Another Nematoda species, Philometra oreoleucisci Moravec \& Ergens, 1970, was one of the numerous parasites of $O$. potanini found exclusively in the caudal fin of the fish. The nematodes were revealed in all three studied lakes, but their abundance was higher in the lakes Khar and Khar Us (Table 1). The life cycle of Ph. oreoleucisci has not been studied. But copepods are most likely the first intermediate hosts, as for other Philometra species (Moravec, 1994). It is possible that a future study of Copepoda in terms of parasites noted in the water bodies of the Great Lakes Depression (Krylov, 2013; Krylov et al., 2018) will clarify this issue.

Eleven helminth species parasitised fish on larval stages in the body cavity, cranial cavity and eyes. In the body cavity, we found nematodes Contracaecum sp., cestode Dibothriocephalus dendriticus Nitzsch, 1824 and trematode Hysteromorpha triloba (Rudolphi, 1819). Single plerocercoids D. dendriticus were found in the lakes Khar and Khar Us only (Table 1). Larvae of Contracaecum sp. and Hysteromorpha triloba metacercariae had both a high prevalence and mean abundance in fish in all three lakes. The first intermediate hosts of $D$. dendriticus are copepods (Pugachev, 2002). Fish get infected by eating infected invertebrates. According by the infection rates, the proportion of Crustacea is very small in the diet. And our data on diet spectrum of $O$. potaninin have confirmed this. 
Table. List of parasites of Oreoleuciscus potanini and fish infection rates in the three lakes of Khar Us Nuur National Park

\begin{tabular}{|c|c|c|c|c|c|c|c|c|c|}
\hline \multirow{2}{*}{ Parasite species } & \multicolumn{3}{|c|}{ Lake Khar $(\mathrm{n}=22)$} & \multicolumn{3}{|c|}{ Lake Khar Us $(\mathrm{n}=19)$} & \multicolumn{3}{|c|}{ Lake Durgen $(\mathrm{n}=11)$} \\
\hline & E & $\mathrm{M}$ & $\min -\max$ & $\mathrm{E}$ & \begin{tabular}{l|l}
$\mathrm{M}$ & 1 \\
\end{tabular} & $\min -\max$ & $\mathrm{E}$ & $\mathrm{M}$ & $\min -\max$ \\
\hline \multicolumn{10}{|c|}{ Phylum Acanthocephala } \\
\hline \multicolumn{10}{|c|}{ Class Eoacanthocephala } \\
\hline Neoechinorhynchus rutili (Müller, 1780) & 27 & $\begin{array}{c}0.4 \\
(0.14-0.82) \\
\end{array}$ & $1-3$ & 26 & $\begin{array}{c}0.37 \\
(0.11-0.63) \\
\end{array}$ & $1-2$ & 9 & \begin{tabular}{|c|}
0.09 \\
$(0.00-0.27)$ \\
\end{tabular} & (1) \\
\hline \multicolumn{10}{|c|}{ Phylum Annelida } \\
\hline \multicolumn{10}{|c|}{ Class Clitellata } \\
\hline Piscicola geometra (Linnaeus, 1761) & 64 & $\begin{array}{c}1.1 \\
(0.64-1.55)\end{array}$ & $1-4$ & 58 & $\begin{array}{c}1.3 \\
(0.7-2.0)\end{array}$ & $1-5$ & - & - & - \\
\hline \multicolumn{10}{|c|}{ Phylum Nematoda } \\
\hline \multicolumn{10}{|c|}{ Class Enoplea } \\
\hline Pseudocapillaria tomentosa (Dujardin, 1843) & 14 & $\begin{array}{c}0.7 \\
(0.14-1.90) \\
\end{array}$ & $3-8$ & 11 & $\begin{array}{c}0.16 \\
(0.00-0.47)\end{array}$ & $1-2$ & - & - & - \\
\hline \multicolumn{10}{|c|}{ Class Chromadorea } \\
\hline Contracaecum sp., 1 & 100 & $\begin{array}{c}7.18 \\
(2.0-28.2) \\
\end{array}$ & $1-106$ & 100 & $\begin{array}{c}6.21 \\
(5.16-7.47) \\
\end{array}$ & $3-12$ & 73 & $\begin{array}{c}1.3 \\
(0.7-1.9)\end{array}$ & $1-3$ \\
\hline Philometra oreoleucisci Moravec \& Ergens, 1970 & 80 & $\begin{array}{c}4.2 \\
(2.82-5.77) \\
\end{array}$ & $1-13$ & 75 & $\begin{array}{c}3.6 \\
(2.32-5.29) \\
\end{array}$ & $1-12$ & 100 & $\begin{array}{c}9.2 \\
(7.45-11.60) \\
\end{array}$ & $4-18$ \\
\hline Rhabdochona humili Roytman \& Trofimenko, 1964 & 32 & $\begin{array}{c}1.27 \\
(0.55-2.54) \\
\end{array}$ & $1-8$ & 47 & $\begin{array}{c}1.6 \\
(0.74-2.95) \\
\end{array}$ & $1-8$ & 45 & \begin{tabular}{|c|}
0.64 \\
$(0.18-1.09)$ \\
\end{tabular} & $1-2$ \\
\hline \multicolumn{10}{|c|}{ Phylum Platyhelminthes } \\
\hline \multicolumn{10}{|c|}{ Class Cestoda } \\
\hline Caryophyllaeides fennica (Schneider, 1902) & 14 & $\begin{array}{c}0.23 \\
(0.00-0.55) \\
\end{array}$ & $1-2$ & 26 & \begin{tabular}{c|}
0.4 \\
$(0.16-0.89)$ \\
\end{tabular} & $1-3$ & - & - & - \\
\hline Dibothriocephalus dendriticus Nitzsch 1824, pl & 14 & $\begin{array}{c}0.14 \\
(0.00-0.27)\end{array}$ & $1-1$ & 21 & $\begin{array}{c}0.21 \\
(0.00-0.37) \\
\end{array}$ & $1-1$ & - & - & - \\
\hline Proteocephalus torulosus (Batsch, 1786) & 55 & $\begin{array}{c}6.6 \\
(2.14-17.90) \\
\end{array}$ & $1-55$ & 74 & $\begin{array}{c}2.6 \\
(1.47-4.36) \\
\end{array}$ & $1-11$ & 55 & $\begin{array}{c}1.4 \\
(0.54-2.30) \\
\end{array}$ & $1-5$ \\
\hline \multicolumn{10}{|c|}{ Class Monogenea } \\
\hline Dactylogyrus ersinensis Spassky \& Roytman, 1960 & 17 & $\begin{array}{c}0.2 \\
(0.05-0.32) \\
\end{array}$ & $1-1$ & 11 & $\begin{array}{c}0.1 \\
(0.00-0.22) \\
\end{array}$ & $1-1$ & 9 & \begin{tabular}{|c|}
0.01 \\
$(0.00-0.27)$ \\
\end{tabular} & (1) \\
\hline Dactylogyrus oreoleucisci Ergens \& Dulmaa, 1970 & 13 & $\begin{array}{c}0.18 \\
(0.00-0.41) \\
\end{array}$ & $1-2$ & 5 & $\begin{array}{c}0.16 \\
(0.00-0.47) \\
\end{array}$ & (3) & 9 & $\begin{array}{c}0.01 \\
(0.00-0.27) \\
\end{array}$ & (1) \\
\hline Gyrodactylus llewellyni Ergens \& Dulmaa, 1967 & 8 & $\begin{array}{c}0.14 \\
(0.00-0.36)\end{array}$ & $1-2$ & 5 & $\begin{array}{c}0.05 \\
(0.00-0.16) \\
\end{array}$ & (1) & - & - & - \\
\hline Gyrodactylus mongolicus Ergens \& Dulmaa, 1970 & 75 & $\begin{array}{c}4.5 \\
(3.01-5.95)\end{array}$ & $2-13$ & 42 & $\begin{array}{c}1.16 \\
(0.47-2.47) \\
\end{array}$ & $1-3$ & 27 & $\begin{array}{c}0.4 \\
(0.09-0.54) \\
\end{array}$ & $1-1$ \\
\hline Gyrodactylus oreoleuciscus Ergens \& Dulmaa, 1970 & 88 & $\begin{array}{c}4.7 \\
(3.14-6.64) \\
\end{array}$ & $1-15$ & 79 & $\begin{array}{c}2.9 \\
(1.47-4.47)\end{array}$ & $1-12$ & 64 & $\begin{array}{c}1.4 \\
(0.64-2.00) \\
\end{array}$ & $1-3$ \\
\hline Gyrodactylus pewzowi Ergens, 1980 & 80 & $\begin{array}{c}2.4 \\
(1.73-3.14) \\
\end{array}$ & $1-7$ & 95 & $\begin{array}{c}1.3 \\
(1.00-1.63) \\
\end{array}$ & $1-3$ & 82 & $\begin{array}{c}1.2 \\
(0.64-1.64)\end{array}$ & $1-2$ \\
\hline \multicolumn{10}{|c|}{ Class Trematoda } \\
\hline Allocreadium isoporum (Looss, 1894) & 59 & $\begin{array}{c}5.1 \\
(2.33-10.50)\end{array}$ & $3-32$ & 58 & $\begin{array}{c}4.94 \\
(2.89-7.63)\end{array}$ & $4-16$ & - & - & - \\
\hline Allocreadium transversale (Rudolphi, 1802) & 18 & $\begin{array}{c}0.5 \\
(0.09-1.27)\end{array}$ & $1-5$ & 5 & $\begin{array}{c}0.1 \\
(0.00-0.32)\end{array}$ & $(2)$ & - & - & - \\
\hline Diplostomum pseudospathaceum Niewiadomska, 1984, mtc & 50 & $\begin{array}{c}1.8 \\
(1.04-2.91)\end{array}$ & $2-8$ & 47 & $\begin{array}{c}0.95 \\
(0.42-1.68)\end{array}$ & $1-5$ & - & - & - \\
\hline Diplostomum spathaceum (Rudolphi, 1819), mtc & 73 & $\begin{array}{c}2.7 \\
(1.68-4.09)\end{array}$ & $1-11$ & 68 & $\begin{array}{c}1 \\
(0.58-1.47)\end{array}$ & $1-3$ & 100 & $\begin{array}{c}3.6 \\
(2.45-4.64)\end{array}$ & $1-7$ \\
\hline $\begin{array}{l}\text { Diplostomum sp. LIN2 Blasco-Costa, Faltynkova, Georgieva, } \\
\text { Skirnisson, Scholz, Kostadinova, 2014, mtc }\end{array}$ & 9 & $\begin{array}{c}0.3 \\
(0.00-1.09)\end{array}$ & $2-5$ & 21 & $\begin{array}{c}0.8 \\
(0.21-1.84)\end{array}$ & $2-6$ & - & - & - \\
\hline Hysteromorpha triloba (Rudolphi, 1819), mtc & 67 & $\begin{array}{c}51 \\
(28.1-81.8) \\
\end{array}$ & $1-170$ & 79 & \begin{tabular}{c|c}
46 \\
$(31.1-60.70)$
\end{tabular} & $22-113$ & 100 & $\begin{array}{c}10 \\
(6.82-12.1)\end{array}$ & $1-17$ \\
\hline Ichthyocotylurus pileatus (Rudolphi, 1802), mtc & 64 & $\begin{array}{c}5.6 \\
(3.55-8.30)\end{array}$ & $2-17$ & 47 & \begin{tabular}{c|}
4.3 \\
$(2.11-7.84)$
\end{tabular} & $4-23$ & 82 & $\begin{array}{c}4.7 \\
(2.64-7.45)\end{array}$ & $1-13$ \\
\hline Ornithodiplostomum scardinii (Shulman in Dubinin, 1952), mtc & 14 & $\begin{array}{c}0.14 \\
(0.00-0.27)\end{array}$ & $1-1$ & 11 & $\begin{array}{c}0.16 \\
(0.00-0.43)\end{array}$ & $1-2$ & 9 & $\begin{array}{c}0.01 \\
(0.00-0.27)\end{array}$ & (1) \\
\hline Posthodiplostomum brevicaudatum (Nordmann, 1832), mtc & 23 & $\begin{array}{c}1.14 \\
(0.32-2.59)\end{array}$ & $1-9$ & 16 & $\begin{array}{c}0.16 \\
(0.00-0.32)\end{array}$ & $1-1$ & 9 & $\begin{array}{c}0.01 \\
(0.00-0.27)\end{array}$ & (1) \\
\hline Tylodelphys cerebralis (Chakrabarti, 1968), mtc & 5 & $\begin{array}{c}0.09 \\
(0.00-0.23)\end{array}$ & $1-1$ & 11 & $\begin{array}{c}0.05 \\
(0.00-0.32)\end{array}$ & $(2)$ & 9 & $\begin{array}{c}0.01 \\
(0.00-0.27)\end{array}$ & (1) \\
\hline Tylodelphys clavata (Nordmann, 1832), mtc & 18 & $\begin{array}{c}0.27 \\
(0.05-0.55)\end{array}$ & $1-2$ & 11 & $\begin{array}{c}0.11 \\
(0.00-0.26)\end{array}$ & $1-1$ & 9 & $\begin{array}{c}0.01 \\
(0.00-0.27) \\
\end{array}$ & (1) \\
\hline Total parasite species & & 26 & & & 26 & & & 15 & \\
\hline
\end{tabular}

Note: $\mathrm{n}$ - number of fish dissected; $\mathrm{E}$ - prevalence (\%); M - mean abundance; 1 - larva; $\mathrm{pl}$ - plerocercoid; mtc - metacercaria. In brackets - 95\% confidential limits for the population mean abundance by the BCa method with 2000 bootstrap replications (Reiczigel et al., 2019). 
The first intermediate hosts of Contracaecum sp. are numerous invertebrate species, e.g. copepods and larvae of dragonflies, and dipterans (Moravec, 1994). A considerable number of various invertebrates resides in the River Dzabkhan basin (Krylov et al., 2018; Prokin, 2018). Larvae of Contracaecum spp. are very difficult for identification according to morphology before the third development stage (Moravec, 1994). Probably three Contracaecum species (Contracaecum rudolphii Hartwich, 1964, C. microcephalum (Rudolphi, 1809), C. spasskii Mozgovoi, 1950) can parasitise on O. potanini as well as on other fish species in the Great Lakes Depression. We found adult nematodes C. rudolphii and C. microcephalum in Phalacrocorax carbo sinensis Shaw \& Nodder, 1801 and Larus argentatus mongolicus Suschkin, 1925 on the Khar Lake shore, respectively (Lebedeva \& Chantuu, 2015). In addition, we observed third stage larvae of $C$. microcephalum in Barbatula conilobus in the River Dzabkhan (Lebedeva et al., 2019). Additionally, the finding of nematodes C. rudolphii and C. spasskii in birds in China increases the likelihood to reveal these species in Mongolia (Li et al., 2013).

Snails of the genus Gyraulus are the first intermediate hosts for the trematode Hysteromorpha triloba. After leaving the snails, cercariae actively penetrate into the fish skin and then move to the body cavity. This species parasitises in different fish not only in the Holarctic, but also in the Neotropical region, by ending the development only in the specific host Phalacrocorax carbo (Locke et al., 2011; Sereno-Uribe et al., 2018a). Adults of $H$. triloba were previously founded in $P h$. carbo from the Khar Lake shore (Lebedeva \& Chantuu, 2015).

Metacercariae of Ichthyocotylurus pileatus $(\mathrm{Ru}-$ dolphi, 1802) were present in a large number in the body cavity of $O$. potanini sampled in all three lakes (Table 1). In addition, several parasites were found in eyes retina of fishes. To date, various development stages of I. pileatus have been identified using molecular methods in Canada, Great Britain and the Czech Republic (Bell et al., 2001; Locke et al., 2010; Heneberg et al., 2018). The first intermediate hosts of the parasite are Valvata spp. snails, while the final hosts are fish-eating birds. It is believed that Ichthyocotylurus pileatus is a parasite of Coregonidae and Percidae fish (Niewiadomska, 2001). However, in the water bodies of the Great Lakes Depression, $O$. potanini, as the dominating fish species, assumes the role of an intermediate host.

Five Trematoda species were isolated from the eyes of $O$. potanini. There were three species in the lens: Diplostomum spathaceum (Rudolphi, 1819), D. pseudospathaceum Niewiadomska, 1984 and Diplostomum sp. LIN2 Blasco-Costa, Faltynkova, Georgieva, Skirnisson, Scholz, Kostadinova, 2014. All parasite species invaded the fish with active swimming cercariae. Metacercariae of Diplostomum spathaceum were very numerous in all three water bodies. It seems that $D$. spathaceum is widespread in the whole of Mongolia. Metacercariae of the species were also found in the eye lenses of Thymallus brevirostris in water bodies of the River Dzabkhan basin. Additionally, Rutilus rultulus from Lake Terkhiin Tsagaan (Arctic Ocean basin) was infected by this trematode. Adults of $D$. spathaceum were found in intestine of Larus argentatus (Lebedeva \& Chantuu, 2015; Lebedeva et al., $2015,2020)$. Two other representatives of the genus were D. pseudospathaceum and Diplostomum sp. LIN2. They were less numerous in fish from the lakes Khar and Khar Us only. Diplostomum pseudospathaceum seems to have the same list of hosts as D. spathaceum (Pérez-del-Olmo et al., 2014; Locke et al., 2015; Hoogendoorn et al., 2020). The host range and geographical distribution of Diplostomum sp. LIN2 requires further study, because the metacercaria have been found only in distinct Iceland and Mongolia (Blasco-Costa et al., 2014; Faltýnková et al., 2014; Lebedeva et al., 2020).

Few metacercariae of Posthodiplostomum brevicaudatum (Nordmann, 1832) and Tylodelphys clavata (Nordmann, 1832) were isolated from vitreous humor of fish eyes in the three lakes investigated. Both parasites invaded the fish with active swimming cercariae. The first intermediate hosts for P. brevicaudatum are the snails Planorbis planorbis (Linnaeus, 1758) and P. carinatus Müller, 1774, and the final hosts are fish-eating birds like Ardea spp. and Sterna spp. (Sudarikov et al., 2002). For Tylodelphys clavata, the first intermediate hosts were snails of the genus Lymnaea and the final ones are several fish-eating bird species (Sudarikov et al., 2002).

In the cranial cavity of $O$. potanini, two species, Ornithodiplostomum scardinii (Shulman in Dubinin, 1952) and Tylodelphys cerebralis (Chakrabarti, 1968), were observed. Few metacercariae of both species parasitise fish in the lakes Khar and Khar Us. According to Chaudhary et al. (2017), metacercariae of $T$. cerebralis could be localised not only in the cranial cavity but also in the vitreous humor of eyes. The diplostomoid larvae, including the genus Tylodelphys, are morphologically very similar. Also some new species of the genus Tylo- 
delphys have been isolated from new hosts in different parts of the world in recent years (Sokolov et al., 2013; Otachi et al., 2015; Chaudhary et al., 2017; Sereno-Uribe et al., 2018b). Therefore, it is necessary to conduct further investigations (preferably using molecular methods) on fish metacercariae in Mongolia. The adult trematodes of both genera are parasites of piscivorous birds, like Ardea spp. and Sterna spp. (Sudarikov et al., 2002; Sitko \& Rzad, 2014; Stoyanov et al., 2017).

The high diversity of parasites completing their development in birds as well as high invasion rates of $O$. potanini in the studied lakes are most likely associated with the wide distribution and increasing in number of fish-eating birds in the Khar Us Nuur National Park (Zvonov et al., 2016). On the other hand, fish feeding with algae and macrophytes provides spatial contact with the cercariae escaping the snails and increases the infection of fish with trematodes. A high abundance of parasites (Contracaecum microcephalum, $C$. rudolphii, Dibothriocephalus dendriticus, Hysteromorpha triloba, Diplostomum spathaceum, D. pseudospathaceum) was found in bird intestine on the Khar Lake shore that evidences that fish take significant part of birds' diet.

Among 26 parasites revealed in O. potanini, only five species were the most specific for this host (monogeneans Gyrodactylus mongolicus, $G$. oreoleucisci, G. pewsowi and nematodes Philometra oreoleucisci, Rhabdochona humili). These parasites were described from Oreoleusiscus potanini only as well as the geographic range of these species is limited to the water bodies of Western Mongolia (Pugachev, 2002). Monogeneans Gyrodactylus llewellyni, Dactylogyrus ersinensis and D. oreoleucisci were firstly revealed as parasites of Oreoleuciscus species only. But later species of Phoxinus and Rhynchocypris were found to be hosts for the parasites (Pugachev, 2002). It seems that these species are more common with fish in the Asian part of the Palaearctic.

The 21 species found are parasites of different fish with wide geographical range. Species as Neoechinorhynchus rutile, Caryophyllaeides fennica and Pseudocapillaria tomentosa are widespread in the Holarctic. They are parasites of various freshwater fish, mainly Cyprinidae (Pugachev, 2002, 2004). Ichthyocotylurus pileatus also have been identified in different parts of the Holarctic (Bell et al., 2001; Locke et al., 2010; Heneberg et al., 2018). In water bodies of Mongolia, O. potanini is the only final host for Proteocephalus toru- losus. But in general, P. torulosus is a widespread parasite of Cyprinidae fish in the Holarctic (Anikieva et al., 1987; Pugachev, 2002; Anikieva, 2004). The trematodes Diplostomum spp., Posthodiplostomum brevicaudatum, Ornithodiplostomum scardinii, and Tylodelphys clavata are common in the Palearctic waters (Locke et al., 2015; Stoyanov et al., 2017; Hoogendoorn et al., 2020). Allocreadium isoporum is a widespread parasite of Cyprinidae fish in the Palearctic (Petkevičiūte et al., 2010), while the status and biology of Allocreadium transversale, as well as its distribution, need further research. Piscicola geometra is a parasite of many fish species in water bodies of the Northern Hemisphere (Pugachev, 2004).

In general, comparison of the parasite species composition of fish between the three studied water bodies showed the depletion of the latter in Lake Durgen. In this water body, O. potanini had only 15 parasite species, while there were no parasites associated with other hosts except of $O$. potanini (Table 1). The infection intensity of these parasites were also low in the lakes Khar and Khar Us. It is likely that, despite the ability of fish to exist in conditions of higher salinity (Mironovsky et al., 2019), parasites have not managed to adapt to these conditions. Alternatively, another possible reason for the absence of these parasites in Lake Durgun is a decrease of invertebrates in the biomass. This in its turn is determined by two factors, including the deterioration of the hydrodynamic conditions due to a decrease in water level and an increase in the load from the catchment due to the Durgun reservoir creation (Krylov, 2013). By analysing the parasite species composition of $O$. potanini in the Great Lakes Depression, we can assume that it has not changed considerably since the 1980 s (Kazakov \& Paranlejamts, 1985; Paranlejamts, 1993; Roitman et al., 1997; Pugachev, 2002, 2003, 2004). Earlier, 32 helminth species were identified in the Great Lakes Depression basin (Roitman et al., 1997; Pugachev, 2002, 2003, 2004). According to Roitman et al. (1997), in Lake Durgen, the number of species was also lower than in the lakes Khar and Khar Us. However, specific parasites as Gyrodactylus mongolicus and G. oreoleucisci were not recorded in the Lake Durgen. In our study, the rare nematode Eustrongylides mergorum (Rudolphi, 1809) was not recorded. In addition, we have not found the cestode Paradilepis scolecina (Rudolphi, 1819) in O. potanini. Previously, both parasites were detected in this host species from different water bodies of Mongolia (Pugachev, 2002). 
But adult Paradilepis scolecina were revealed in intestine of Phalacrocorax carbo in the Khar Lake shore (Lebedeva \& Chantuu, 2015). Alternatively, it is possibly associated with the small fish sampling compared with previous studies (e.g. Kazakov \& Paranlejamts, 1985; Paranlejamts, 1993; Roitman et al., 1997; Pugachev, 2002, 2003, 2004). Moreover, fluctuations of fish infection rates by year are possible. For example, in 2011, the infection of O. potanini by Proteocephalus torulosus in Lake Har-Nuur amounted to 13\% (two specimens of 15 fish examined), under infection rate of 18 and 40 specimens, and abundance index of 3.9 specimens (Anikieva et al., 2013). This is several times lower than in our study (Table 1).

But some differences in the species list could be associated with taxonomic renaming and the development of the phylogeny of certain parasite groups, e.g. for the trematodes Diplostomum spp. According to previously published data, O. potani$n i$ is a host for nine species of diplostomids (Roitman et al., 1997; Pugachev, 2003; Batueva, 2011). A comprehensive study of $O$. potanini metacercaria from different locations in the Central Asian Inland Basin showed the presence of three species only named as $D$. pseudospathaceum, D. spathaceum and Diplostomum sp. LIN2. In Mongolian water bodies, a total of five Diplostomum species were found. Additionally Diplostomum baeri Dubois, 1937 was revealed in Perca fluviatilis and $D$. mergi Dubois, 1932 in Barbatula conilobus from Lake Terkhiin Tsagaan and River Dzabkhan, respectively (Lebedeva et al., 2015, 2020). Further investigation of $O$. potanini could identify new diplostomids. Similarly, recent studies of cestodes from the Diphyllobothriidae attributed representatives of Diphyllobothrium dendriticum (Nitzsch, 1824) to Dibothriocephalus dendriticus (Waeschenbach et al., 2017).

Oreoleuciscus species form an endemic fish group in Central Asia, belonging to the Cyprinidae. According to paleontological data, this is a relatively young group. Fossil records of ancestral oreoleuciscoid forms date back to the border between the Pliocene and Pleistocene. In particular, on the basis of the analysis of the nucleotide sequence polymorphism of the mitochondrial DNA, it was established that the close relatives of $O$. potanini are phoxinine fish belonging to the genera Phoxinus, Rhynchocypris, Tribolodon, and Pseudoaspius. Moreover, the closest relationships were discovered between Oreoleuciscus potanini and Rhynchocypris. lagowskii (Dybowski, 1869)
(Slynko \& Borovikova, 2012; Kartavtsev et al., 2017; Sakai et al., 2020). In Western Mongolia, Oreoleuciscus potanini resides in various water bodies, including fresh and brackish-water lakes, streams, rivers, located at altitudes of 700-2500 m a.s.l. The noncompetitive evolution of a relatively young group developing in a region with exceptionally variable environmental conditions (Sokolov \& Shatunovsky, 1983) led to its extremely high morphological diversity and genetic heterogeneity (Slynko \& Dgebuadze, 2009).

Data on the parasite fauna of $O$. potanini confirmed the evolutionary youth of this fish group. Some of the parasites found are considered to be endemics and specific parasites found only in Oreoleuciscus spp. (Gyrodactylus mongolicus, G. oreoleucisci, G. pewsowi, Philometra oreoleucisci, Rhabdochona humili). The formation of these species as valid ones occurred probably after Oreoleuciscus diverged from the other Leuciscinae fishes (Roitman et al., 1997). Some parasites were noted in $O$. potanini as well as in the phylogenetically closest fish of the genera Phoxinus and Rhynchocypris. So, the monogeneans Gyrodactylus llewellyni, Dactylogyrus ersinensis and D. oreoleucisci indicate a phylogenetic relationship between these host species in the Central Asian Inland Basin and western Mongolia. Pugachev (2001) reported on the same situation with the parasite Myxobolus mongolicus Pronin, 1973. It was previously considered to be an endemic of the West Mongolian Province as a specific parasite of $O$. potanini. But later it was found in Thymallus brevirostris and Rhynchocypris percnurus from the River Lena and River Selenga, as well as in the Far East. Parasites are evolved in parallel with their hosts. The complementary adaptations of parasites and their hosts are formed over a long co-evolution (Bykhovsky, 1957). These data were obtained using molecular methods for many monogeneas (e.g. Ziętara \& Lumme, 2003; Vanhove et al., 2014; Lumme et al., 2017). In our materials, an example is the invasion of $O$. potanini with all specific parasites in oligotrophic brackish-water of Lake Durgen, while some of the non-specific ones were absent in the lake's fish parasite fauna (Table 1). Additionally, some helminthes (Caryophyllaeides fennica, Proteocephalus torulosus) parasitise on different fish species, but mainly on Cyprinidae. In Mongolia, they parasitise only on $O$. potanini. The high morphological variability of $P$. torulosus on Oreoleuciscus potanini confirmed the adaptation of the parasite and the host to extremely variable environmental 
conditions of the region as co-evolution (Anikieva et al., 1987, 2013). The other group includes many widespread parasite species such as Diplostomum spp., Ichthyocotylurus pileatus, Tylodelphys spp., Hysteromorpha triloba, Allocreadium spp., and Contracaecum spp.. Perhaps due to adaptation to the only host $O$. potanini, these helminthes have being in the process of micro evolution and eventually the formation of new species. Therefore, since parasites co-evolve with hosts, information on their species composition can be useful in addressing the systematics of Oreoleuciscus fish, any changes in their biology, and can also help in the study of ecosystem dynamics as a whole.

\section{Conclusions}

It could be assumed that the current situation with the Oreoleuciscus spp. divergence and their spreading was formed in the Pleistocene, in the Chibanian period (Sytchevskaya, 1989). So, a part of their parasite fauna including endemics was formed at the same time before the fish divergence from the ancestral form. The absence of considerable long-term changes in the parasite composition indicates that the ecosystem of water bodies in the Khar Us Nuur National Park is in sufficient balance, where parasites are an integral biodiversity component. The fauna of this Protected Area is diverse. It presents a variety of organism groups involved in the development of parasites at different stages.

However, discussion of the parasite fauna richness of $O$. potanini requires further investigation to compare the species composition of hosts from various water bodies. Additionally, studies based on molecular genetics of the parasites taxonomy are required to allow re-descriptions of species morphology. Consequently, further study needs to concentrate the attention on these two points to collect data on the species composition of both parasites and hosts. In addition, parasite taxonomy is developing, requiring molecular studies and redescriptions of species morphology.

\section{Acknowledgments}

The authors are grateful to Dr. Pugachev O.N. and Dr. Gerasev P.I. (Zoological Institute of RAS, Russia) for consulting on parasite identification. Special thanks for helping to improve the text and valuable comments are extended to Prof. Marek S. Ziętara (University of Gdańsk, Poland), Drs. Campbell C. Pert and Tatiana Dovgan (Marine Scotland Science, Marine Laboratory, United Kingdom). The study was supported by the Joint Russian-Mongolian Biological Expedition of the Russian Academy of Sciences and the Mongolian Academy of Sciences (2011) and by the state order 0218-2019-0075.

\section{References}

Anikieva L.V. 2004. Variability and phenotypic structure of Proteocephalus torulosus (Cestoda: Proteocephalidea) - a parasite of cyprinid fishes. Parazitologiia 38(2): 171-179. [In Russian]

Anikieva L.V., Pugachev O.N., Paranlejamts J. 1987. Cestodes of the genus Proteocephalus from Altai Osman (Oreoleuciscus: Cyprinidae). In: O.A. Scarlato (Ed.): Proceedings of the Zoological Institute RAS. Systematics, faunistics, morphology of parasitic organisms. Vol. 161. Leningrad: Nauka. P. 94-106. [In Russian]

Anikieva L.V., Lebedeva D.I., Mendsajhan B. 2013. Morphological variability and the structure of pre-reproductive age group of the cestode Proteocephalus torulosus from Altai Osman (Oreoleuciscus, Cyprinidae) in water bodies of Mongolia. Parazitologiya 47(5): 380-389. [In Russian]

Batueva M.D. 2011. The parasite fauna and structures of parasite communities of Oreoleuciscus humilis Warpachowski, 1889 from Ust-Nur Lake (Selenga River basin) and Tuin-Gol River (Goby Lakes Valley). Parazitologiya 45(5): 379-383. [In Russian]

Bell A., Sommerville C., Valtonen E.T. 2001. A molecular phylogeny of the genus Ichthyocotylurus (Digenea, Strigeidae). International Journal for Parasitology 31(8): 833-842. DOI: 10.1016/s0020-7519(01)00181-3

Blasco-Costa I., Faltynkova A., Georgieva S., Skirnisson K., Scholz T., Kostadinova A. 2014. Fish pathogens near the Arctic Circle: molecular, morphological and ecological evidence for unexpected diversity of Diplostomum (Digenea: Diplostomidae) in Iceland. International Journal for Parasitology 44(10): 703-715. DOI: 10.1016/j.ijpara.2014.04.009

Boomker J. 1994. Parasites of South African freshwater fish. VI. Nematode parasites of some fish species in the Kruger National Park. Onderstepoort Journal of Veterinary Research 61(1): 35-43.

Borkhanuddin M.H., Cech G., Molnár K., Németh S., Székely C. 2014. Description of raabeia, synactinomyxon and neoactinomyxum developing stages of myxosporeans (Myxozoa) infecting Isochaetides michaelseni Lastočkin (Tubificidae) in Lake Balaton and Kis-Balaton Water Reservoir, Hungary. Systematic Parasitology 88(3): 245-259. DOI: 10.1007/s11230-014-9496-1

Borutsky E.V. (Ed.). 1974. Practical Manual on Analysis of Feeding and Food Relationships of Fishes in Natural Conditions. Moscow: Nauka. 254 p. [In Russian]

Bush A.O., Lafferty K.D., Lotz J.M., Shostak A.W. 1997. Parasitology meets ecology on its own terms: Margolis et al. revisited. Journal of Parasitology 83(4): 575-583. DOI: $10.2307 / 3284227$

Butorina T.E., Shedko M.B., Gorovaya O.Yu. 2008. Specific Features of Ecology of Chars of the Genus Salvelinus (Salmonidae) from the Basin of Lake Kronotskoe (Kamchatka) According to Parasitological Data. Jour- 
nal of Ichthyology 48(8): 622-636. DOI: 10.1134/ S0032945208080080

Bykhovskaya-Pavlovskaya I.E. 1985. Parasites of fishes. Study Manual. Leningrad: Nauka. 123 p. [In Russian]

Bykhovsky B.E. 1957. Monogenea, their system and phylogeny. Moscow; Leningrad: AS USSR 509 p. [In Russian]

Chaudhary A., Tripathi R., Gupta S., Singh H.S. 2017. First report on molecular evidence of Tylodelphys cerebralis (Diplostomulum cerebralis) Chakrabarti, 1968 (Digenea: Diplostomidae) from snakehead fish Channa punctata. Acta Parasitologica 62(2): 386-392. DOI: 10.1515/ap-2017-0046

Chugunova N.I. 1959. Fish study guide. Moscow: AS USSR. 163 p. [In Russian]

Chunchukova M., Kirin D. 2018. New data on endohelminth communities of barbel Barbus barbus from the Bulgarian part of the River Danube. Helminthologia 55(3): 222-229. DOI: 10.2478/helm-2018-0016

Chunchukova M., Shukerova S., Kirin D. 2016. Research of the impact of the river Danube on the Srebarna Biosphere Reserve by the model ecosystem Abramis brama - Macroinvertebrates - Sediments. Agricultural Sciences 8 (19): 151-158. DOI: 10.22620/ agrisci.2016.19.023

Dgebuadze Yu.Yu., Dulmaa A., Munkhbayar Kh. 2003. On finding of a Representative of the Genus Oreoleuciscus (Cypinidae) in the Selenga Basin. Journal of Ichthyology 43(3): 420-422. [In Russian]

Dgebuadze Yu.Yu., Batnasan N., Berdovskaya G.N., Verzilin N.N., Devyatkin E.V., Dorofeyuk N.I., Dulmaa A., Egorov A.N., Kalmykova N.A., Korneva L.G., Kosolapova N.G., Krylov A.V., Kulikovsky M.S., Liiva A.A., Luvsandorzh N., Martinson G.G., Mensaikhan B., Neustrueva I.Yu., Nikolaeva T.V., Petukhov V.A., Ponomarenko A.G., Przhiboro A.A., Prokin A.A., Rasskazov A.A., Sanchir G., Sevastyanov D.V., Skvortsov V.V., Hand Yo., Tsarenko P.M., Tsugar S., Tseresodnom J., Tsetsegmaa D., Chebotarev E.N., Shuvalov V.F. 2014. Lynmology and paleolymnology of Mongolia. Vol. 60. Moscow: Biological Resources and Natural Conditions of Mongolia. 412 p. [In Russian]

Dgebuadze Yu.Yu., Mironovskii A.N., Mendsaikhan B., Slynko Yu.V. 2017. The First Case of Morphological Differentiation of Altai Osman Oreoleuciscus potanini (Cyprinidae, Actinopterigii) in a River. Doklady Biological Sciences 473(2): 57-60. DOI: 10.1134/ S0012496617020053

Dgebuadze Yu.Yu., Mironovskii A.N., Mendsaikhan B., Slynko Yu.V. 2020. Rapid Morphological Diversification of the Cyprinid Fish Oreoleuciscus potanini (Cyprinidae) in the Course of Formation of a Reservoir in a River of the Semiarid Zone. Doklady Biological Sciences 490(1): 12-15. DOI: 10.1134/S0012496620010019

Ergens R., Dulmaa A. 1970. Monogenoidea from fishes of the genus Oreoleuciscus (Cyprinidae) from Mongolia. Folia Parasitologica 17(1): 1-11.
Faltýnková A., Georgieva S., Kostadinova A., Blasco-Costa I., Scholz T., Skirnisson K. 2014. Diplostomum von Nordmann, 1832 (Digenea: Diplostomidae) in the subArctic: descriptions of the larval stages of six species discovered recently in Iceland. Systematic Parasitology 89(3): 195-213. DOI: 10.1007/s11230-014-9517-0

Galli P., Benzoni F., Strona G., Stefani F., Kritsky D.C. 2007. Monogenoidean parasites of fishes associated with coral reefs in the Ras Mohammed National Park, Egypt: preliminary results. Helminthologia 44(2): 76-79. DOI: 10.2478/s11687-007-0007-7

Halajian A., Smales L.R., Tavakol S., Smit N.J., Luus-Powell W. J. 2018. Checklist of acanthocephalan parasites of South Africa. ZooKeys 789: 1-18. DOI: 10.3897/ zookeys.789.27710

Heneberg P., Sitko J., Tesinsky M., Rzad I., Bizos J. 2018. Central European Strigeidae Railliet, 1919 (Trematoda: Strigeidida): Molecular and comparative morphological analysis suggests the reclassification of Parastrigea robusta Szidat, 1928 into Strigea Abildgaard, 1790. Parasitology International 67(6): 688-701. DOI: 10.1016/j.parint.2018.07.003

Hoogendoorn C., Smit N.J., Kudlai O. 2020. Resolution of the identity of three species of Diplostomum (Digenea: Diplostomidae) parasitising freshwater fishes in South Africa, combining molecular and morphological evidence. International Journal for Parasitology: Parasites and Wildlife 11: 50-61. DOI: 10.1016/j.ijppaw.2019.12.003

Hyslop E.J. 1980. Stomach contents analysis - a review of methods and their application. Journal of Fish Biology 17(4): 411-429. DOI: $10.1111 / \mathrm{j} .1095$ 8649.1980.tb02775.x

Kartavtsev Y.P., Batischeva N.M., Bogutskaya N.G., Katugina A.O., Hanzawa N. 2017. Molecular systematics and DNA barcoding of Altai osmans, Oreoleuciscus (Pisces, Cyprinidae, and Leuciscinae), and their nearest relatives, inferred from sequences of cytochrome b (Cytb), cytochrome oxidase c (Co-1), and complete mitochondrial genome. Mitochondrial DNA Part A 28(4): 502-517. DOI: 10.3109/24701394.2016.1149822

Kazakov B.E., Paranlejamts J. 1985. To the study of the fauna and ecology of helminths of Altai Osmans in Western Mongolia. In: Theoretical and practical problems of the study of helminths. Moscow. P. 70-86. [In Russian]

Khalil L.F., Jones A., Bray R.A. (Eds.). 1994. Keys to the cestode parasites of vertebrates. Wallingford: CABI. $768 \mathrm{p}$.

Kirjušina M., Vismanis K. 2007. Checklist of the parasites of fishes of Latvia. Rome: FAO Fisheries Technical Paper. No. 369/3. 106 p.

Krylov A.V. 2013. Quantitative development of zooplankton in waterbodies and watercourses of the Great Lakes Depression (Mongolia). Inland Water Biology 6(1): 32-38. DOI: $10.1134 /$ S1995082912040098

Krylov A.V., Mendsaikhan B., Ayushsuren Ch., Tsvetkov A.I. 2018. Zooplankton of the coastal areas of reservoirs of 
the arid zone: effects of level regime and meteorological conditions. Ecosystem Transformation 1(1): 5-23. DOI: $10.23859 /$ estr-180319

Lebedeva D.I., Chantuu Kh. 2015. New data on bird helminths in Mongolia. Parazitologiya 49(4): 304-308.

Lebedeva D.I., Mendsaikhan B., Chantuu Kh., Jargalmaa G., 2015. Helminths of the Common roach (Rutilus rutilus Linnaeus, 1758) and the European Perch (Perca fluvialitis Linnaeus, 1758) in the Lake Terkhiin Tsagaan (Mongolia). Parazitologiya 49(2): 98-103. [In Russian]

Lebedeva D.I., Karabanov D.P., Zaicev D.O., Mendsayhan B., Yakovleva G.A. 2019. Parisites of the Stoan loache Barbatula conilobus (Balitoridae: Nemacheilinae) in the Dzabkhan River (Mongolia). Parazitologiya 53(4): 348-352. DOI: 10.1134/S0031184719040069 [In Russian]

Lebedeva D.I., Yakovleva G.A., Zaytsev D.O., Mendsaikhan B. 2020. Trematode Metacercariae in the eyes of fish from reservoirs of Mongolia. Ecosystem Transformation 3(1): 19-26. DOI: 10.23859/estr-191017

Li L., Xu Z., Zhang L.P. 2013. Further studies on Contracaecum spasskii Mozgovoi, 1950 and C. rudolphii Hartwich, 1964 (sensu lato) (Ascaridida: Anisakidae) from piscivorous birds in China. Systematic Parasitology 84(3): 225-236. DOI 10.1007/s11230-012-9399-y

Locke S.A., McLaughlin D.J., Marcogliese D.J. 2010. DNA barcodes show cryptic diversity and a potential physiological basis for host specificity among Diplostomoidea (Platyhelminthes: Digenea) parasitizing freshwater fishes in the St. Lawrence River, Canada. Molecular Ecology 19(13): 2813-2827. DOI: 10.1111/j.1365-294X.2010.04713.x

Locke S.A., McLaughlin J.D., Lapierre A.R., Johnson P.T., Marcogliese D.J. 2011. Linking Larvae and Adults of Apharyngostrigea cornu, Hysteromorpha triloba, and Alaria mustelae (Diplostomoidea: Digenea) Using Molecular Data. Journal of Parasitology 97(5): 846-851. DOI: $10.1645 / \mathrm{GE}-2775.1$

Locke S.A., Al-Nasiri F.S., Caffara M., Drago F., Kalbe M., Lapierre A.R., McLaughlin J.D., Nie P., Overstreet R.M., Souza G.T.R., Takemoto R.M., Marcogliese D.J. 2015. Diversity, specificity and speciation in larval Diplostomidae (Platyhelminthes: Digenea) in the eyes of freshwater fish, as revealed by DNA barcodes. International Journal for Parasitology 45(13): 841-855. DOI: 10.1016/j.ijpara.2015.07.001

Lumme J., Ziętara M.S., Lebedeva D. 2017. Ancient and modern genome shuffling: Reticulate mito-nuclear phylogeny of four related allopatric species of Gyrodactylus von Nordmann, 1832 (Monogenea: Gyrodactylidae), ectoparasites on the Eurasian minnow Phoxinus phoxinus (L.) (Cyprinidae). Systematic Parasitology 94(2): 183-200. DOI: 10.1007/s11230-016-9696-y

Mendsaikhan B., Dulmaa A., Krylov A.V., Slynko Yu.V., Prokin A.A., Demidsereter S., Dgebuadze Yu.Yu.,
Lebedeva D.I., Atlantcenceg B. 2015. The state of the fish population of the Taishir reservoir (Western Mongolia) after its filling. In: N.I. Dorofeyuk, S.N. Bazha, Yu.I. Drobyshev, A.V. Andreev, S.-Kh.D. Syrtypova, N. Saruul (Eds.): Ecosystems of Central Asia in modern conditions of social and economic development. Vol. 2. Ulaan-Baatar, Mongolia: Bembi San. P. 65-68. [In Russian]

Mironovsky A.N., Mavrin A.S., Kozhara A.V., Slynko Yu.V. 2019. Salinity Factor in the Microevolution of Fishes and Redistribution of Age Groups of Altai Osman Oreoleuciscus potanini (Cyprinidae) in Ayrag and Khyargas Lakes, Mongolia. Russian Journal of Ecology 50(3): 307-309. DOI: 10.1134/S106741361903010X

Molnár K., Gibson D.I., Cech G., Papp M., Deák-Paulus P., Juhász L., Tóth N., Székely C. 2015. The occurrence of metacercariae of Petasiger (Digenea: Echinostomatidae) in an unusual site, within the lateral line scales of cyprinid fishes. Folia Parasitologica 62: 017. DOI: 10.14411/fp.2015.017

Moravec F. 1994. Parasitic nematodes of freshwater fishes of Europe. Praga: Springer Netherlands. 473 p.

Moravec F. 2001. Common sculpin Cottus gobio as a natural paratenic host of Proteocephalus longicollis (Cestoda: Proteocephalidae), a parasite of salmonids, in Europe. Diseases of Aquatic Organisms 45(2): 155-158. DOI: 10.3354/dao045155

Moravec F., Bakenhaster M. 2010. Philometrid nematodes infecting fishes from the Everglades National Park, Florida, USA, with description of two new species. Folia Parasitologica 57(3): 213-222. DOI: 10.14411/fp.2010.028

Moravec F., Ergens R. 1970. Nematodes from fishes and cyclostomes of Mongolia. Folia Parasitologica 17(3): 217-232.

Morozińska-Gogol J. 2007. Metazoan parasites of fish from the Łebsko Lagoon (Central Coast, Poland). Baltic Coastal Zone 11: 51-58.

Morozińska-Gogol J. 2009. Alien species of fish parasites in the coastal lakes and lagoons of the southern Baltic. Oceanologia 51(1): 105-115. DOI: 10.5697/oc.51-1.105

Mudry D.R., Anderson R.S. 1977. Helminth and arthropod parasites of fishes in the mountain national parks of Canada. Journal of Fish Biology 11(1): 21-33. DOI: 10.1111/j.1095-8649.1977.tb04095.x

Murcia S., Kerans B.L., MacConnell E., Koel T.M. 2006. Myxobolus cerebralis infection patterns in Yellowstone cutthroat trout after natural exposure. Diseases of Aquatic Organisms 71(3): 191-199. DOI: 10.3354/dao071191

Niewiadomska K. 2001. Strigeidae Railliet, 1919. In: D.I. Gibson, A. Jones, R.A. Bray (Eds.): Keys to the Trematoda. Vol. 1. Wallingford, UK: Natural History Museum, London and CAB International. P. 231-241.

Oroš M., Scholz T., Hanzelová V., Mackiewicz J.S. 2010. Scolex morphology of monozoic cestodes (Caryophyl- 
lidea) from the Palaearctic Region: a useful tool for species identification. Folia Parasitologica 57(1): 37-46. DOI: $10.14411 / \mathrm{fp} .2010 .006$

Otachi E.O., Locke S.A., Jirsa F., Fellner-Frank C., Marcogliese D.J. 2015. Morphometric and molecular analyses of Tylodelphys sp. metacercariae (Digenea: Diplostomidae) from the vitreous humour of four fish species from Lake Naivasha, Kenya. Journal of Helminthology 89(4): 404-414. DOI: 10.1017/ S0022149X14000170

Paranlejamts J. 1993. Helminths and other groups of fish parasites of Mongolia (fauna, ecological-faunistic characteristic, zoogeography). PhD Thesis Abstract. Moscow. 33 p. [In Russian]

Pérez-del-Olmo A., Georgieva S., Pula H.J., Kostadinova A. 2014. Molecular and morphological evidence for three species of Diplostomum (Digenea: Diplostomidae), parasites of fishes and fish-eating birds in Spain. Parasites and Vectors 7(1): 502-516. DOI: 10.1186/s13071-014-0502-x

Petkevičiūtė R., Stunžénas V., Stanevičiūtė G., Sokolov S.G. 2010. Comparison of the developmental stages of some European allocreadiid trematode species and a clarification of their life-cycles based on ITS2 and 28S sequences. Systematic Parasitology 76(3): 169-178. DOI: $10.1007 / \mathrm{s} 11230-010-9249-8$

Pravdin I.F. 1966. Fish study guide. Moscow: Nauka. 376 p. [In Russian]

Presswell B., Blasco-Costa I. 2019. Description of Tylodelphys darbyi n. sp. (Trematoda: Diplostomidae) from the threatened Australasian crested grebe (Podiceps cristatus australis, Gould 1844) and linking of its lifecycle stages. Journal of Helminthology 94: e40. DOI: 10.1017/S0022149X19000142

Prokin A.A. 2018. Initial Stage of Macrozoobenthos Formation in Reservoirs of Western Mongolia. Inland Water Biology 11(2): 161-172. DOI: 10.1134/ S1995082918020189

Prokofiev A.M. 2016. Loaches of the Genus Barbatula (Nemacheilinae) of the Zavkhan River Basin (Western Mongolia). Journal of Ichthyology 56(6): 818-831. DOI: $10.7868 / \mathrm{S} 0042875216060084$

Pugachev O.N. 2001. Checklist of the freshwater fish parasites of the Northern Asia. Protozoa. Saint-Petersburg: Zoological Institute RAS. 240 p. [In Russian]

Pugachev O.N. 2002. Checklist of the freshwater fish parasites of the Northern Asia. Cnidaria, Monogenoidea, Cestoda. Saint-Petersburg: Zoological Institute RAS. 238 p. [In Russian]

Pugachev O.N. 2004. Checklist of the freshwater fish parasites of the Northern Asia. Nematoda, Acanthocephala, Hirudinea, Mollusca, Crustacea, Acari. Saint-Petersburg: Zoological Institute RAS. 250 p. [In Russian]

Pugachev O.N. 2003. Checklist of the freshwater fish parasites of the Northern Asia. Trematoda. Saint-Petersburg: Zoological Institute RAS. 224 p. [In Russian]
Pugachev O.N., Gerasev P.I., Gussev A.V. Ergens R., Khotenowsky I. 2010. Guide to monogenoidea of freshwater fish of Palaeartic and Amur regions. Milano: LedizioniLedipublishing. 567 p.

Reiczigel J., Marozzi M., Fabian I., Rozsa L. 2019. Biostatistics for parasitologists - a primer to Quantitative Parasitology. Trends in Parasitology 35(4): 277-281. DOI: 10.1016/j.pt.2019.01.003

Roitman V.A., Kazakov B.E., Perenlejzhamc Zh.K. 1997. Taxonomic and ecological diversity of helminthes of osmans (Oreoleuciscus spp.) in the water bodies of Mongolia. Proceedings of Institute of Parasitology 41: 120-130. [In Russian]

Rózsa L., Reiczigel J., Majoros G. 2000. Quantifying parasites in samples of hosts. Journal of Parasitology 86(2): 228-232. DOI: 10.1645/0022-3395(2000)086[0228:QP ISOH]2.0.CO;2

Rubtsova N.Yu., Kutsokon Yu.K. 2018. First note on fish parasites in Polissky Nature Reserve, Northern Ukraine. Vestnik Zoologii 52(1): 53-58. DOI: 10.2478/vzoo2018-0007

Sakai H., Watanabe K., Goto A. 2020. A revised generic taxonomy for Far East Asian minnow Rhynchocypris and dace Pseudaspius. Ichthyological Research 67: 330 334. DOI: 10.1007/s10228-019-00726-5

Sandlund O.T., Daverdin R.H., Choudhury A., Brooks D.R., Diserud O.H. 2010. A survey of freshwater fishes and their macroparasites in the Guanacaste Conservation Area (ACG). NINA Report 635. Costa Rica. 45 p.

Sasal P., Desdevises, Durieux E., Lenfant P., Romans P. 2004. Parasites in marine protected areas: success and specificity of monogeneans. Journal of Fish Biology 64(2): 370-379. DOI: 10.1046/j.1095-8649.2003.00297.x

Scarlato O.A. (Ed.). 1985. Identification Key of Freshwater Fish Parasite Fauna in USSR. Parasitic Multicellular Organisms (First Part). Vol. 2. Leningrad: Nauka. 425 p. [In Russian]

Scarlato O.A. (Ed.). 1987. Identification Key of Freshwater Fish Parasite Fauna in USSR. Parasitic Multicellular Organisms (Second Part). Vol. 3. Leningrad: Nauka. 583 p. [In Russian]

Scholz T., Ergens R. 1990. Cestodes of fishes from Mongolia. Acta Societatis Zoologicae Bohemoslovacae 54: 287-304.

Scholz T., Choudhury A., Brooks D.R. 2019. A new species of Synbranchiella (Cestoda: Proteocephalidae) from the mountain Mullet (Dajaus Monticola) in Costa Rica. Journal of Parasitology 105(1): 79-84. DOI: 10.1645/18-71

Sereno-Uribe A.L., López-Jimenez A., Andrade-Gómez L., García-Varela M. 2018a. A morphological and molecular study of adults and metacercariae of Hysteromorpha triloba (Rudolpi, 1819), Lutz 1931 (Diplostomidae) from the Neotropical region. Journal of Helminthology 93(1): 91-99. DOI: 10.1017/S0022149X17001237

Sereno-Uribe A.L., Andrade-Gómez L., Ponce de León G.P., García-Varela M. 2018b. Exploring the genetic diversity of Tylodelphys (Diesing, 1850) metacercariae in the 
cranial and body cavities of Mexican freshwater fishes using nuclear and mitochondrial DNA sequences, with the description of a new species. Parasitology Research 118(1): 203-217. DOI: 10.1007/s00436-018-6168-0

Shukerova S.A., Kirin D. 2008. Helminth communities of the rudd Scardinius erythrophthalmus (Cypriniformes, Cyprinidae) from Srebarna Biosphere Reserve, Bulgaria. Journal of Helminthology 82 (4): 319-323. DOI: 10.1017/s0022149x08023857

Shukerova S., Kirin D., Hanzelová V. 2010. Endohelminth communities of the perch, Perca fluviatilis (Perciformes, Percidae) from Srebarna Biosphere Reserve, Bulgaria. Helminthologia 47(2): 99-104. DOI: 10.2478/s11687-010-0016-9

Shukerova S., Kirin D., Chunchukova M., Kuzmanova D. 2017. Helminth fauna of White BREAM (Blicca bjoerkna) (Linnaeus, 1758), from the Srebarna Biosphere Reserve, Bulgaria. Scientific Papers. Series D. Animal Science. Vol. 60. P. 366-371.

Sitko J., Rząd I. 2014. Diplostomum and Ornithodiplostomum scardinii (Diplostomidae, Digenea) species from naturally infected birds (Anatinae) in the Czech Republic and in Poland: morphological, morphometric and ecological features. Helminthologia 51(3): 215-224. DOI: 10.2478/s11687-014-0232-9

Slynko Yu.V., Borovikova E.A. 2012. Phylogeography of Altai osmans fishes (Oreoleuciscus sp., Cyprinidae, Pisces) inferred from nucleotide variation of the mitochondrial DNA cytochrome b gene. Russian Journal of Genetics 48(6): 618-627. DOI: 10.1134/S1022795412060154

Slynko Yu.V., Dgebuadze Yu.Yu. 2009. Population-genetical analysis of Altai Osmans (Oreoleuciscus, Cyprinidae) from water bodies of Mongolia. Journal of Ichthyology 49(8): 614-626. DOI: 10.1134/S0032945209080050

Sokolov S.G., Gordeev I.I. 2014. The first record of Monogenea (Plathelminthes) parasitic on char (Salmonidae: Salvelinus) from Kronotsky Lake (Kamchatka Peninsula), Russia. Invertebrate Zoology 11(2): 353-359. DOI: 10.15298/invertzool.11.2.06

Sokolov S.G., Lebedeva D.I., Yadrenkina E.N. 2013. The first data on the parasite fauna of Amur sleeper Perccottus glenii Dybowski, 1877 (Actinopterygii: Odontobutidae) from waterbodies of forest- steppe zone of West Siberian plains. Parazitologiya 47(6): 448-460. [In Russian]

Sokolov V.E., Shatunovskiy M.I. (Eds.). 1983. The Fishes of Mongolian People's Republic. Habitat conditions, taxonomy, morphology, zoogeography. Moscow: Nauka. 277 p. [In Russian]

Stoyanov B., Georgieva S., Pankov P., Kudlai O., Kostadinova A., Georgiev B.B. 2017. Morphology and molecules reveal the alien Posthodiplostomum centrarchi Hoffman, 1958 as the third species of Posthodiplostomum Dubois, 1936 (Digenea: Diplostomidae) in Europe. Systematic Parasitology 94(1): 1-20. DOI: 10.1007/ s11230-016-9680-6
Stunžènas V., Petkevičiūtė R., Stanevičiūtè G., Binkienè R. 2014. Rhipidocotyle fennica (Digenea: Bucephalidae) from Anodonta anatina and pike Esox lucius in Lithuania. Parasitology Research 113(10): 3881-3883. DOI: 10.1007/s00436-014-4102-7

Sudarikov V.E., Shigin A.A., Kurochkin Yu.V., Lomakin V.V., Stenko R.P., Yurlova N.I. 2002. Metacercariae of trematodes are the parasites of freshwater hydrobionts of Russia. Vol. 1. Moscow: Nauka. 298 p. [In Russian]

Sytchevskaya E.K. 1989. Neogene freshwater fish fauna of Mongolia. Moscow: Nauka. 144 p. [In Russian]

Székely Cs., Shaharom-Harrison F., Cech G., Ostoros G., Molnár K. 2009. Myxozoan infections in fishes of the Tasik Kenyir Water Reservoir, Terengganu, Malaysia. Diseases of Aquatic Organisms 83: 37-48. DOI: 10.3354/dao01991

Székely Cs., Shaharom F., Cech G., Mohamed K., Mohd Zin N.A., Borkhanuddin M.H., Ostoros G., Molnár K. 2012. Myxozoan infection of the Malaysian mahseer, Tor tambroides, of Tasik Kenyir Reservoir, Malaysia: description of a new species Myxobolus tambroides sp.n. Parasitology Research 111(4): 1749-1756. DOI 10.1007/s00436-012-3020-9

Utevsky A., Sinna E., Smyrov D., Shrestha M., Gamulya Y., Ukhno G., Khodzhaeva R., Utevsky Y., Levenets V., Utevsky S. 2018. Next steps in development of Marine Protected Area in the Argentine Islands Archipelago water area. No. WG-EMM-18/32. Commission for the Conservation of Antarctic Marine Living Resources. 9 p.

Vanhove M., Economou A.N., Zogaris S., Giakoumi S., Zanella D., Volckaert F., Huyse T. 2014. The Gyrodactylus (Monogenea, Gyrodactylidae) parasite fauna of freshwater sand gobies (Teleostei, Gobioidei) in their centre of endemism, with description of seven new species. Parasitology Research 113(2): 653-668. DOI: 10.1007/s00436-013-3693-8

Waeschenbach A., Brabecb J., Scholz T., Littlewood D.T.J., Kuchta R. 2017. The catholic taste of broad tapeworms - multiple routes to human infection. International Journal for Parasitology 47(13): 831-843. DOI: 10.1016/j.ijpara.2017.06.004

Wood C.L., Micheli F., Fernández M., Gelcich S., Castilla J.C., Carvajal J. 2013. Marine protected areas facilitate parasite populations among four fished host species of central Chile. Journal of Animal Ecology 82(6): 12761287. DOI: 10.1111/1365-2656.12104

Ziętara M.S., Lumme J. 2003. The crossroads of molecular, typological and biological species concepts: two new species of Gyrodactylus Nordmann, 1832 (Monogenea: Gyrodactylidae). Systematic Parasitology 55(1): 39-52. DOI: 10.1023/A:1023938415148

Zvonov B.M., Bukreev S.A., Boldbaatar Sh. 2016. Birds of Mongolia. Part I. Non-Passeriformes. (Non-Passeriformes). Moscow: Agricultural Technologies. 396 p. [In Russian] 


\title{
ПАРАЗИТЫ OREOLEUCISCUS POTANINI (CYPRINIDAE) В ОЗЕРАХ НАЦИОНАЛЬНОГО ПАРКА ХАР-УС-НУУР (МОНГОЛИЯ)
}

\author{
Д. И. Лебедева ${ }^{1, *}$, Б. Мендсайхан², Г. А. Яковлева ${ }^{1}$, Д. О. Зайцев ${ }^{3}$ \\ ${ }^{1}$ Институт биологии Карельского научного ичентра РАН, Россия \\ *e-mail:daryal78@gmail.com \\ ${ }^{2}$ Институт географии и геоэкологии, Монгольская академия наук, Монголия \\ ${ }^{3}$ Петрозаводский государственный университет, Россия
}

\begin{abstract}
Пресноводные экосистемы Монголии принадлежат к трем основным центральноазиатским водным бассейнам: Арктический бассейн, бассейн реки Амур и Центральноазиатский внутренний бассейн. Значительную часть последнего занимает Котловина Больших озер. Один из немногих живущих там видов рыб, Oreoleuciscus potanini, является наиболее широко распространенным эндемическим видом в Центральноазиатском регионе. Изучение паразитов O. potanini в Котловине Больших озер не являются регулярными в последние годы. Поэтому данное исследование было проведено с целью изучения видового разнообразия паразитов гельминтов O. potanini на трех озерах национального парка «Хар-Ус-Нуур». Всего в августе 2012 г. на озерах Хар, Хар-Ус и Дурген было собрано 52 экземпляра O. potanini. Помимо паразитофауны были изучены возраст и спектр питания хозяев. Рыбы были исследованы на заражение экто- и эндо-макропаразитами. Видовой состав метацеркарий трематод Diplostomum spp. из глаз рыб исследован с помощью молекулярных методов. В озерах Хар и Хар-Ус возраст рыб варьировал от 4 до 32 лет и от 8 до 35 лет, соответственно. В оз. Дурген исследованы рыбы четырех возрастных групп (9, 10, 11 и 14 лет). Во всех трех озерах основной пищей $O$. potanini служили водоросли и различные насекомые, в том числе личинки семейства Chironomidae. При исследовании питания мы обнаружили, что в озере Дурген важным компонентом рациона питания рыб были ракообразные Cladocera. Рыбы среди объектов питания O. potanini в этом водоеме не отмечены. Всего в ходе исследования было выявлено 26 видов паразитов в трех озерах. Общая фауна представлена четырьмя типами, включая Acanthocephala (один вид), Annelida (один вид), Nematoda (четыре вида), Platyhelminthes (двадцать видов). Последняя группа была наиболее многочисленной и разнообразной, включая три вида Cestoda, шесть видов Monogenea и 11 видов Trematoda. Пять видов паразитов были специфичны только для O. potanini (моногенеи Gyrodactylus mongolicus, G. oreleucisci, G. pewsowi, нематоды Philometra oreoleucisci и Rhabdochona humili). Остальные гельминты демонстрировали низкую специфичность хозяев, так как паразитируют у широкого круга рыб в Голарктике. В фауне паразитов преобладают личинки эндогельминтов. Большинство этих паразитов проникают в рыбу через различные виды беспозвоночных во время питания ими $O$. potanini. Наше исследование выявило новые данные о видовом разнообразии метацеркарий Diplostomum spp. в глазах O. potanini. Они представлены тремя видами: Diplostomum spathaceum, D. pseudospathaceum и Diplostomum sp. LIN2. Видовое богатство и разнообразие паразитов было значительно выше для O. potanini из озер Хар и Хар-Ус (26 видов), чем для O. potanini в оз. Дурген (15 видов). Возможной причиной отсутствия некоторых паразитов в последнем водоеме является повышенная соленость воды. Несмотря на то, что рыба может существовать в условиях повышенной солености, вероятно, паразиты (или их беспозвоночные хозяева) не приспособлены к ней. Наши исследования позволили уточнить видовой состав паразитов в озерах национального парка Хар-Ус-Нуур, в том числе охарактеризованы уникальные сообщества паразитов в экосистемах Котловины Больших озер. Результаты исследований паразитофауны $O$. potanini подтверждают сведения об эволюционной молодости группы рыб рода Oreoleuciscus.
\end{abstract}

Ключевые слова: бассейн, видовой состав, гельминт, Котловина Больших озер, река Дзабхан, рыбы, эндемик 